\title{
Tropical marine fish from Celukan Bawang Port, Buleleng, Bali, Indonesia
}

\author{
Rizkyanti Aulia ${ }^{1,}{ }^{*}$, Riskha Hanifa $^{1}$, Nassa Arfiantinosa ${ }^{1}$, Aris Mahmudi $^{2}$, Mohamad Nurul \\ Huda $^{3}$ \\ ${ }^{1}$ PT Mitra Hijau Indonesia, Biological Cluster, Jl. Kertomenanggal 3 no. 5 Surabaya, Indonesia \\ ${ }^{2}$ PT Mitra Hijau Indonesia, Hidro-Oceanography Cluster, Jl. Kertomenanggal 3 no. 5 Surabaya, \\ Indonesia \\ ${ }^{3}$ Universitas Brawijaya, Aquaculture Master Student, Jl. Veteran Malang, Indonesia
}

\begin{abstract}
Celukan Bawang port is located in Buleleng Regency, Bali, Indonesia. The area of Celukan Bawang Port has a coral reef ecosystem that is very rarely found in Indonesian ports. The coral reef has an important role for coral reef fish as their habitat. This study aims to conduct coral reef fish in the Celukan Bawang port area. A survey was conducted by using UVC (Underwater Visual Census) method at four (4) stations in October 2019. The coral-reef fish family identified in this research consisted of 853 individuals belonging to 14 families and 34 species. The dominant family were Pomacentridae (63.53\%), Labridae (25.21\%), Achanthuridae (2.70\%), Chaetodontidae (1.17\%), and Ptereleotrididae $(1.17 \%)$. The most abundant species were Dascyllus trimaculatus (2270 ind/ha), Halichoeres prosopeion (1550 ind/ha), and Pomacentrus coelestis (95 ind/ha). Shannon-Wiener diversity index value was 2.414 , and there were no dominant species observed.
\end{abstract}

\section{Introduction}

North Bali waters in Buleleng District has potential areas as water tourism with 157,05 km beach length and beautiful underwater tourism. Potential activities in the area are swimming, diving, snorkeling, fishing, enjoying sunrise and sunset, and dolphin activity. However, North Bali was called the port city by the Netherland country from the $10^{\text {th }}$ century because it became a regional, national, and international trade route [1]. Nowadays, several ancient ports are non-active and replaced by more critical ports such as Celukan Bawang port.

Celukan Bawang is one of the ports in Bali that have several activities as shipping, unloading container and goods, cement Tonasa packing, and unloading bulk asphalt. This port is a collecting port [2]. The primary function is to provide domestic transportation, transfer domestic area transportation in medium quantities, origin for passengers and goods, and ferry transportation with the provincial service area [3].

Tropical marine fish related with reef fish is a fish associated with a coral reef that stays and forages there. If the coral reef is damaged, the abundance and diversity of marine fish

\footnotetext{
*Corresponding author: rizkyanti.aulia@gmail.com
} 
would be affected [4]. Port activities have the potential to generate wastes, such as from (1) Fuel in a machine room, cooler system, pipe or tank of the ship or other effect from the ship; (2) Shipload activity that create spill and waste from loading, ballast tank cleaning and ballast system; and (3) Domestic waste in blackwater [5]. Those conditions could directly affect the water quality and, in turn, disturb the coral reef ecosystem.

There is no complete data on reef fish in Celukan Bawang. Therefore this study aims to conduct coral reef fish in this port area. This paper will be useful as a reference for environmental management in the area.

\section{Materials and methods}

\subsection{Study site and collecting data}

Field observations were conducted in October 2019 at the Celukan Bawang Port area in Penguin Village, Buleleng District, Bali, Indonesia.

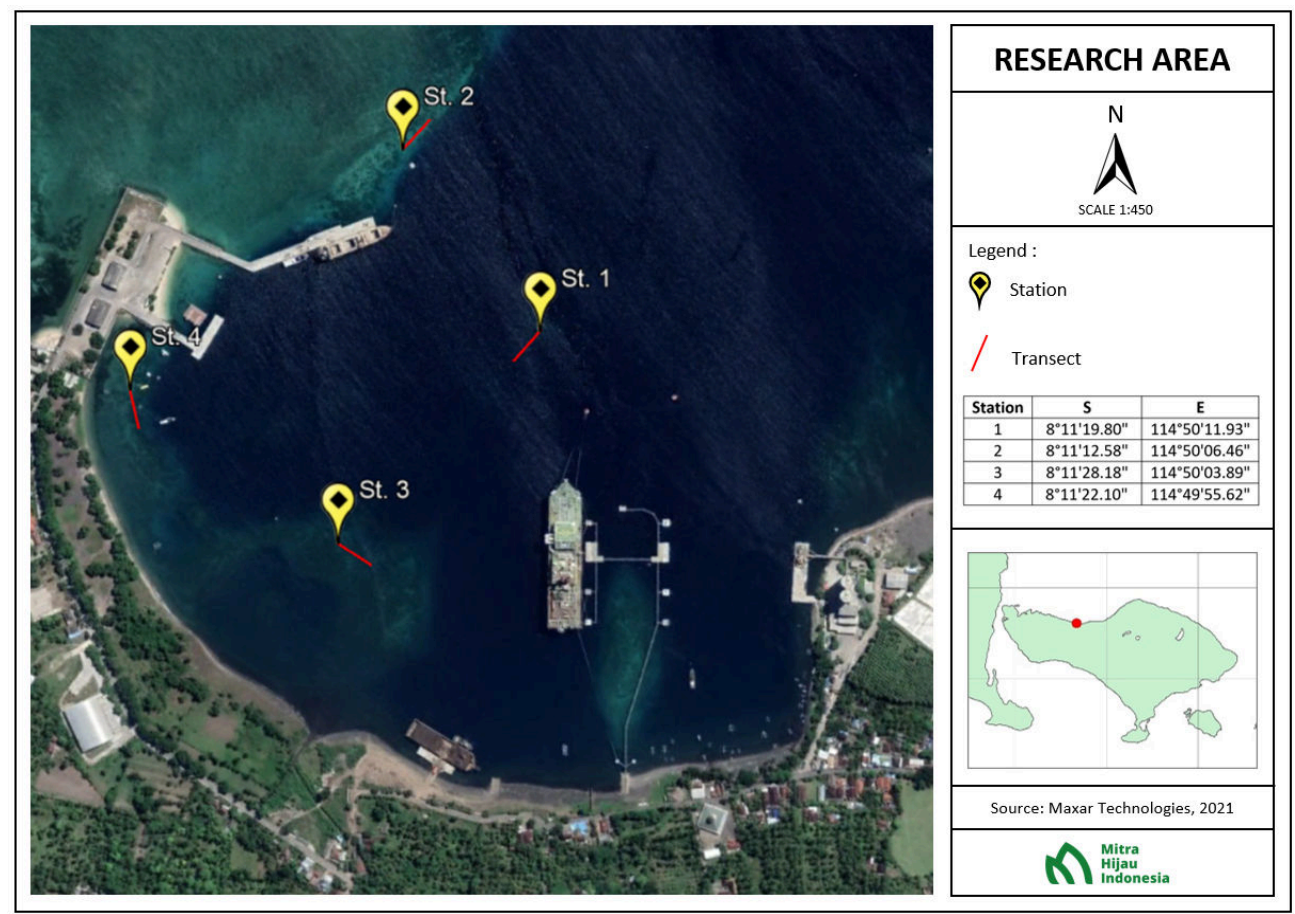

Fig. 1. Study area.

The method for collecting data was Reef Visual Census (RFVS), or familiar as Underwater Visual Census (UVC), by focusing on functional groups of fish [6]. The method focused on the fish census at sufficient resolution to analyze the individual and active group. The transect was placed in 4 locations (Figure 1). Impermanent belt transects were laid in every site (Fig. 2). The census area was $50 \mathrm{~m}$ x 5. Fish numbers by species were counted visually and recorded on waterproof papers. The species was validated by using Kuiter \& Tonozuka (2001) and Allen (2012) [7] [8]. The conservation status of each species was checked based on IUCN Red List. 


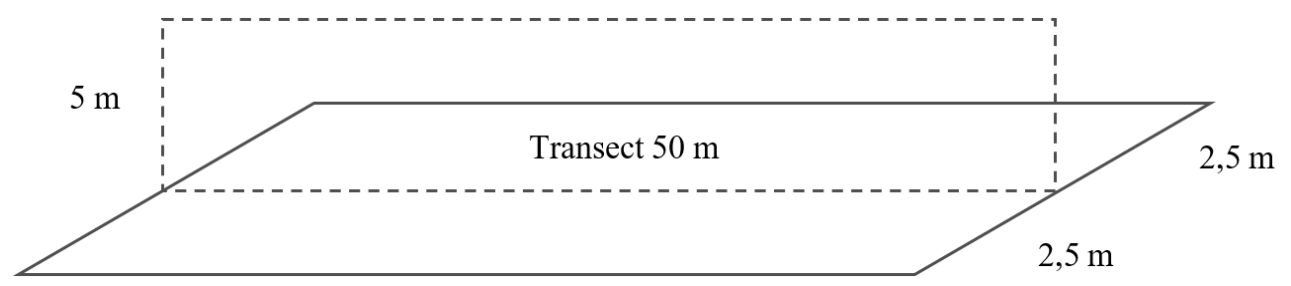

Fig. 2. Survey area dimension by UVC method.

\subsection{Water quality}

Seawater quality parameters were measured based on Government Regulation number 22 2021. Appendix VII concerning Sea Water Quality Standards for Aquatic Biota [9]. Samples were analyzed by KAN accredited laboratory.

\subsection{Data analysis}

Fish data identified then grouped as a functional group: target species, indicator species, or major species. Ecological parameters such as diversity index $\left(\mathrm{H}^{\prime}\right)$ and dominance index $(\mathrm{C})$ by using:

\subsubsection{Abundance and relative abundance}

$$
D=\frac{\Sigma n i}{A}
$$

$\mathrm{D}=$ abundance (ind $/ \mathrm{Ha}$ )

$\mathrm{Ni}=$ number of individual of species (ind)

$\mathrm{A}=\operatorname{area}(\mathrm{Ha})$

$$
R D=\frac{n i}{N} \times 100 \%
$$

$\mathrm{RD}=$ abundande (ind/Ha)

$\mathrm{Ni}=$ number of individual of species (ind)

$\mathrm{A}=\operatorname{area}(\mathrm{Ha})$

\subsubsection{Diversity index}

$$
H^{\prime}=-\sum_{i=1}^{s} P i \ln P i
$$

$$
\begin{aligned}
& \mathrm{H}^{\prime}=\text { Shannon-Wiener index } \\
& \mathrm{Pi}=\text { ni/N } \\
& \mathrm{ni}=\text { number of individual of species }-\mathrm{i} \\
& \mathrm{N}=\text { total number of individual } \\
& \mathrm{S}=\text { number of species }
\end{aligned}
$$


Criteria :

$\begin{array}{ll}\mathrm{H}^{\prime} \leq 1 & =\text { low diversity } \\ 1<\mathrm{H}^{\prime} \leq 3 & =\text { moderate diversity } \\ \mathrm{H}^{\prime} \geq 3 & =\text { high diversity }\end{array}$

\subsubsection{Dominance index}

$$
C=-\sum_{i=1}^{s} P i^{2}
$$

$\mathrm{C}=$ Dominance index

$\mathrm{Pi}=$ proportion of individuals in certain species compared with a total individual of all species

Criteria :

$0<\mathrm{C}<0.5 \quad=$ low dominance

$0.5<\mathrm{C} \leq 0.75=$ moderate dominance

$0.75<\mathrm{C} \leq 1 \quad=$ high dominance

\section{Result and discussion}

\subsection{Sea water quality}

The results of seawater quality are summarized in Table 1 . The results show no parameters exceeding the quality standards based on Government Regulation No 22 Appendix VIII (2021) regarding seawater quality standards for aquatic biota [9].

Table 1. Water quality parameters.

\begin{tabular}{|c|l|c|c|c|}
\hline No & \multicolumn{1}{|c|}{ Parameter } & Unit & Quality Standards & Result \\
\hline 1 & Clarity & meter & $>5$ & $5-7$ \\
\hline 2 & Temperature & ${ }^{\circ} \mathrm{C}$ & $28-30$ & $31-32$ \\
\hline 3 & $\mathrm{pH}$ & - & $7-8.5$ & $8-8.7$ \\
\hline 4 & Salinity & $\% 0$ & $33-34$ & $34.4-34.5$ \\
\hline 5 & TSS & $\mathrm{mg} / \mathrm{L}$ & 20 & $<2-2$ \\
\hline 6 & Oil layer & - & absent & absent \\
\hline
\end{tabular}

All of the parameters except for clarity are above the range of quality standards for aquatic biota. The clarity is also in line with standards quality which is good. Meanwhile, other parameters exceed the quality standard so that the coral could tolerate this condition. It can be assumed that all environmental parameters in the study area are suitable for coral growth.

\subsection{Coral condition}

Based on Ministry of Environment of the Republic of Indonesia no 4 (2001) about Standard Criteria for Coral Reef Damage [11], the coral coverage of Celukan Bawang Port Coral was between low to middle coverage. The locations with a Coral range of 7,04\% and $17,14 \%$ are categorized as low coverage. Meanwhile, The locations with coral coverage of $-32,72 \%$ and $25,14 \%$ are classified as middle coverage. 
Mainly at the sediments of the locations were characterized by coral rubble and sand. By interviewing local people explained that this condition was caused by fish bombing before. The port activities could be caused by sediment agitation, which floated in the water and covered coral polyps. The polyps that are covered by sediment can experience disruption of respiration, reproduction, and metabolic processes that can cause death [12].

\subsection{Abundance and fish community}

The result from fish data analysis is shown in Table 2. Fishes found were generally ornamental fishes. Eight hundred and fifty-three fishes were observed during this study belonging to 34 species and 14 families with a total abundance of $8530 \mathrm{ind} / \mathrm{ha}$. Compared to research in another spot in Bali, this study has a lower number than research in Pamuteran and Sumber Kima waters. In Pamuteran, there were 3419 fishes and 4547 fishes in Sumber Kima [13]. The damaged coral condition causes this condition.

Table 2. Composition and abundance of fish

\begin{tabular}{|c|c|c|c|c|c|c|c|}
\hline No & Family & Species & Name & ni & $\begin{array}{l}\text { Abundance } \\
\text { (ind/Ha) }\end{array}$ & $\begin{array}{c}\text { Relative } \\
\text { abundance } \\
(\%)\end{array}$ & $\begin{array}{c}\text { IUCN } \\
\text { Red List } \\
\text { Status }\end{array}$ \\
\hline 1 & Achanthuridae & Acanthurus mata & Yellowmask surgeonfish & 23 & 230 & 2.696 & $\mathrm{LC}$ \\
\hline 2 & Apogonidae & Apogon hartzfeldii & Silver-lined cardinalfish & 5 & 50 & 0.586 & $\mathrm{NE}$ \\
\hline 3 & Apogonidae & Apogon novemfasciatus & Sevenstriped cardinalfish & 1 & 10 & 0.117 & $\mathrm{NE}$ \\
\hline 4 & Apogonidae & Cheileodipterus quinquelineatus & Three-spot cardinalfish & 2 & 20 & 0.234 & $\mathrm{NE}$ \\
\hline 5 & Blenniidae & Aspidontus taeniatus & False cleanerfish & 1 & 10 & 0.117 & $\mathrm{LC}$ \\
\hline 6 & Caesionidae & Caesio teres & Yellow and blueback fusilier & 7 & 70 & 0.821 & LC \\
\hline 7 & Chaetodontidae & Chaetodon adiergastos & Eye-patch butterflyfish & 3 & 30 & 0.352 & LC \\
\hline 8 & Chaetodontidae & Chaetodon kleinii & Sunburst butterflyfish & 1 & 10 & 0.117 & $\mathrm{LC}$ \\
\hline 9 & Chaetodontidae & Chaetodon lunulatus & Redfin butterflyfish & 4 & 40 & 0.469 & $\mathrm{LC}$ \\
\hline 10 & Chaetodontidae & Chaetodon octofasciatus & Eastern triangular butterflyfish & 1 & 10 & 0.117 & $\mathrm{LC}$ \\
\hline 11 & Chaetodontidae & Chaetodon vagabundus & Vagabond butterflyfish & 1 & 10 & 0.117 & $\mathrm{LC}$ \\
\hline 12 & Gobiidae & Amblygobius noctunus & Flase sleeper goby & 2 & 20 & 0.234 & LC \\
\hline 13 & Haemulidae & Plectorhincus polytaenia & Yellow-ribbon sweetlip & 2 & 20 & 0.234 & $\mathrm{LC}$ \\
\hline 14 & Labridae & Cirrhilabrus solorensis & Red-eyed wrasse & 3 & 30 & 0.352 & DD \\
\hline 15 & Labridae & Halichoeres prosopeion & Half grey wrasse & 155 & 1550 & 18.171 & $\mathrm{LC}$ \\
\hline 16 & Labridae & Thalassoma lunare & Moon wrasse & 57 & 570 & 6.682 & $\mathrm{LC}$ \\
\hline 17 & Lutjanidae & Lutjanus biguttatus & Two-spot snapper & 2 & 20 & 0.234 & LC \\
\hline 18 & Nemipteridae & Scolopsis bilineata & Two-lined monocle bream & 3 & 30 & 0.352 & $\mathrm{LC}$ \\
\hline 19 & Nemipteridae & Scolopsis margaritifer & Perly spinecheek & 5 & 50 & 0.586 & $\mathrm{LC}$ \\
\hline 20 & Plotosidae & Plotosus lineatus & Catfish & 5 & 50 & 0.586 & $\mathrm{LC}$ \\
\hline 21 & Pomacentridae & Abudefduf sexfasciatus & Natal sergeant & 75 & 750 & 8.792 & $\mathrm{LC}$ \\
\hline 22 & Pomacentridae & Amblyglyphidodon aureus & Golden damsel & 24 & 240 & 2.814 & $\mathrm{LC}$ \\
\hline 23 & Pomacentridae & Amblyglyphidodon leucogaster & White-breasted sergeant & 7 & 70 & 0.821 & $\mathrm{LC}$ \\
\hline 24 & Pomacentridae & Chormis amboinensis & Ambon puller & 38 & 380 & 4.455 & $\mathrm{NE}$ \\
\hline 25 & Pomacentridae & Chrysiptera rollandi & Blue-headed damsel & 13 & 130 & 1.524 & $\mathrm{NE}$ \\
\hline 26 & Pomacentridae & Dascyllus melanurus & Back-tailed humbug & 1 & 10 & 0.117 & $\mathrm{NE}$ \\
\hline
\end{tabular}




\begin{tabular}{|c|l|l|l|c|c|c|c|}
\hline No & \multicolumn{1}{|c|}{ Family } & \multicolumn{1}{|c|}{ Species } & \multicolumn{1}{c|}{ Name } & ni & $\begin{array}{c}\text { Abundance } \\
\text { (ind/Ha) }\end{array}$ & $\begin{array}{c}\text { Relative } \\
\text { abundance } \\
(\%)\end{array}$ & $\begin{array}{c}\text { IUCN } \\
\text { Red List } \\
\text { Status }\end{array}$ \\
\hline 27 & Pomacentridae & Dascyllus trimaculatus & Three-spot humbug & 227 & 2270 & 26.612 & VU \\
\hline 28 & Pomacentridae & Dischistodus prospotaenia & Honey-headed damsel & 3 & 30 & 0.352 & NE \\
\hline 29 & Pomacentridae & Pomacentrus chrysurus & White-tail damsel & 7 & 70 & 0.821 & NE \\
\hline 30 & Pomacentridae & Pomacentrus coelestis & Common blue damsel & 95 & 950 & 11.137 & NE \\
\hline 31 & Pomacentridae & Pomacentrus moluccensis & Lemon damsel & 60 & 600 & 7.034 & NE \\
\hline 32 & Pomacentridae & Pomacentrus simsiang & Buleback damsel & 9 & 90 & 1.055 & NE \\
\hline 33 & Ptereleotrididae & Chormis weberi & Weber's chormis & 10 & 100 & 1.172 & NE \\
\hline 34 & Scorpaenidae & Pterois antennata & Spotfin firefish & 1 & 10 & 0.117 & LC \\
\hline \multicolumn{2}{|c|}{ Total } & & $\mathbf{8 5 3}$ & $\mathbf{8 5 3 0}$ & $\mathbf{1 0 0}$ & - \\
\hline
\end{tabular}

Celukan Bawang waters are dominated by the Pomacentridae family with $63.53 \%$ relative abundance and followed by Labridae (25.21\%), Achanthuridae (2.70\%), Chaetodontidae (1.17\%), and Ptereleotrididae (1.17\%). In this study, Pomacentridae is the richest family too because it has 12 species, and the second is Chatodontidae with five species (Figure 3). Compared to other research in Bali, Pomacentridae's abundance and richest is the highest in Pamuteran waters and the second highest in Sumber Kima waters [13].

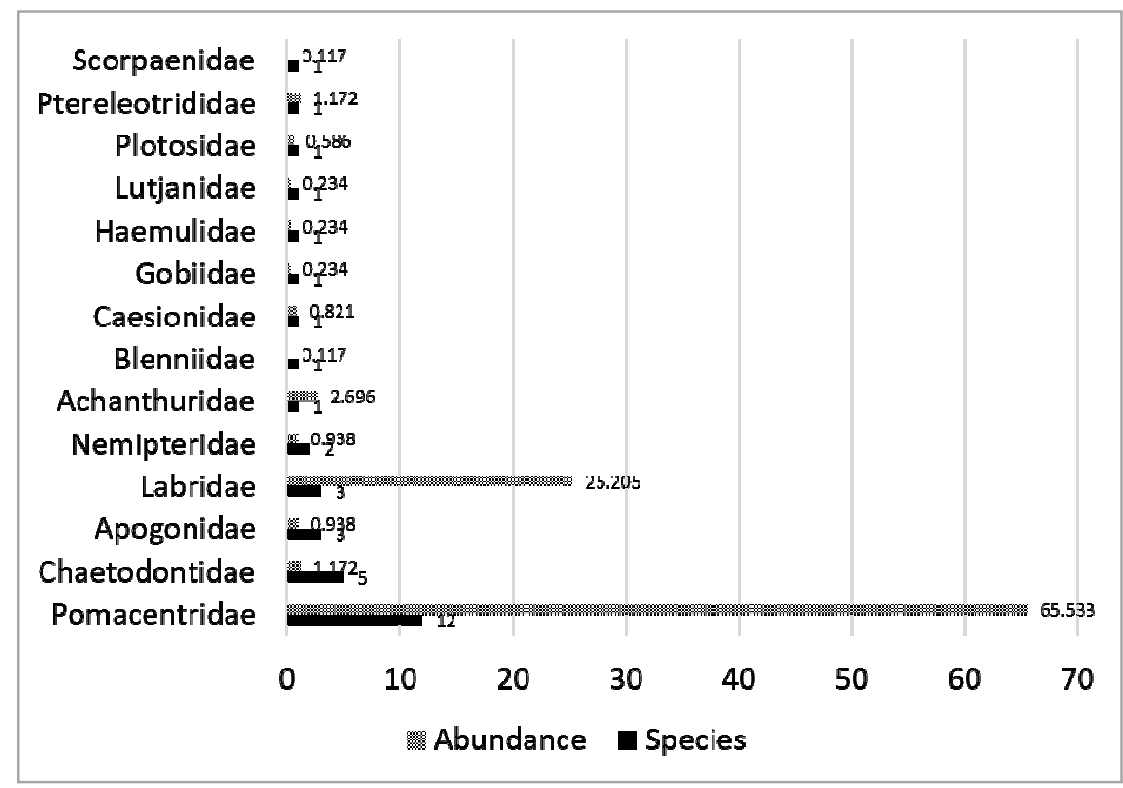

Fig. 3. Fish family comparison in Celukan Bawang area.

Pomacentridae is dominant and the richest family in Celukan Bawang port. Pomacentridae or damselfishes is a large family which has \pm 348 species and 28 genera [14]. They have various individual colors. Some of them are herbivores, omnivores, or planktivores. They put their egg on the seafloor and were kept by the male [15]. Pomacentridae is diurnal fish that are active during the day and swim not far from the 
bottom [16]. We found pomacentrids near the coral reef and swim $0-100 \mathrm{~cm}$ from the bottom during our survey. In this research, Dascyllus trimaculatus, Pomacentrus coelestis, and Abudefduf sexfasciatus have higher abundance in the Pomacentridae family.

Dascyllus trimaculatus known as three-spot humbug or three-spot dascyllus is the largest contributor and the most abundant $(26,612 \%)$ in the Pomacentridae family. Their skin color is dark, bluish-grey, with a white spot on the upper side [17]. They swam in a group but sometimes found solitary near a coral reef, rock, and pile. Dascyllus trimaculatus can be found in Indo-Pacific [8]. They dwell in the coral reef, sometimes the juvenile associated with branching corals or large sea anemones. According to IUCN RedList, Dascyllus trimaculatus is vulnerable. This makes Celukan Bawang Port unique as this species has the highest abundance in this area.

The second position in Pomacentridae, which has high abuncande is Pomacentrus coelestis or common blue damsel. Pomacentrus coelestis has $11.137 \%$ of the total observed fish. Pomacentrus coelestis live around coral reefs and are frequently found around dead coral. It can be located in N.W. Australia, Great Barrier Reef, and also along with S.E. Asia and Indo-C Pacific. It is also known as neon damsel with bright blue dominant color [8]. Based on IUCN RedList, this species is not evaluated because it has not enough data or studied from a scientist.

Abudefduf sexfasciatus has $3^{\text {rd }}$ place after Pomacentrus coelestis with abundance of $8.792 \%$. Also known as natal sergeant or scissortail sergeant, these species live in coral and weedy reefs. The color is white with black streaks in the tail fin. This species is distributed in Indo-C Pacific [8]. According to IUCN RedList, the conservation status is the least concern.

Another family with high abundant species is Halichoeres prosopeion (1550 ind/ha) from Labridae. Halichoeres prosopeion consists $18.171 \%$ of total observed fish. Halichoeres prosopeion live around the coral reef and are often seen in outer slopes. It has a purplish head and anterior part and yellow color in the posterior part. During this survey, we found many juveniles of Halichoeres prosopeion in there. [8]. Compared with other species in the Labridae family, there are Thalassoma lunare or moon wrasse in the second position with $6.682 \%$ abundance and other species in the Labridae family have $<1 \%$ for its abundance.

Chaetodontidae is also known as kepe-kepe fish live in close association with coral reefs. They also become an indicator for coral health. They have various color patterns [18]. When surveying the area, Chaetodontidae is rarely found there. With the coral condition dominated by dead coral, it makes sense why this family was found in low abundance.

The biological index is shown in Table 3. The diversity index (H') of marine fish in Celukan Bawang Port Area is 2.414. Therefore the fish community has moderate diversity. There were no dominant species in the area which was indicated by dominance index (C) below 0.5. A high coral cover does not always follow a high diversity index. In Batbitim Misool, Papua concluded that outside marine conservation areas had higher fish diversity than inside areas. The inside area had a higher coral cover which provided protection and feeding place to certain fishes, so it might be possible that there were dominant species [19]. In this research, even though there was disturbance like port activities, it does not support the dominance of one or more species. With that condition, there might have been a dominant species because fishes have a different tolerance range. Therefore, frequent monitoring in this area is required to know the relation of port activity with the fish community. 
Table 3. Biological index of fish

\begin{tabular}{|l|c|}
\hline \multicolumn{1}{|c|}{ Biological Index } & Value \\
\hline Diversity index $\left(\mathrm{H}^{\prime}\right)$ & 2.414 \\
\hline Dominance index $(\mathrm{C})$ & 0.138 \\
\hline
\end{tabular}

\subsection{Fish group proportion}

It is well known that there are always specific interactions or responses between organisms in coral reef areas. Tropical marine fish could be differentiated into three groups: target species, indicator species, and; major species. Target species is a group of fish which are targeted by fisherman such us Acanthuridae, Haemulidae, Caesionidae, Nemipteridae, Serranidae, Scaridae, Labridae, Lethrinidae, Lutjanidae, Siganidae [19]. Indicator species are a functional group of fish that indicate coral health, like the Chaetodontidae family. Major species consist of fish groups commonly found at coral reefs, and their function in an ecosystem is unknown other than as trophic groups [20].

Fish group proportion in Celukan Bawang Port Area is shown in Fig. 4. Marine fish found are generally ornamental fish. They form fish schools-with various colors and shapes. Major fish has the highest percentage of the total fish population $(58.82 \%)$, followed by target fish (26.47\%) and indicator fish (14.71\%). This composition is normal, especially with a high composition of indicator fish. This condition is similar to Sumbawa waters, with $50.63 \%$ major fish, 34.5\% target fish, and 13\% indicator fish [21]. Fish community composition will depend on substrate characteristics [22] and also human activity. In this area, there are traditional boats from local people for fishing. This area is limited for port activity, so no fishing and diving is allowed. But the composition shows that the target percentage is sufficient $(26.47 \%)$.

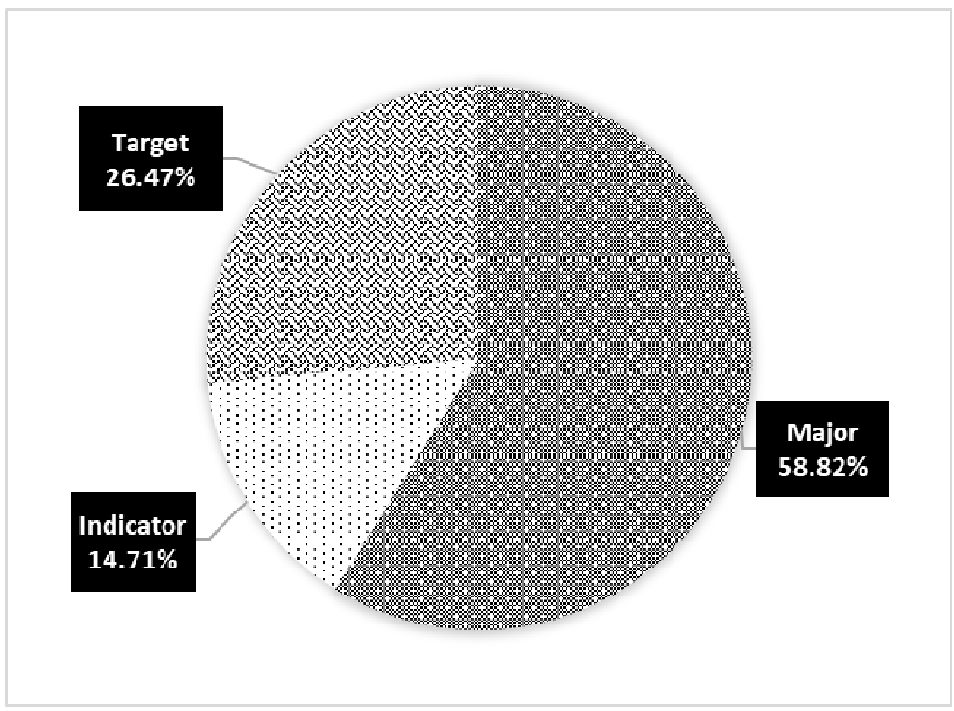

Fig. 4. Fish group composition. 


\section{Conclusion}

Celukan Bawang port waters are suitable for coral growth. The coral-reef fish family identified in this research consisted of 853 fish in 14 families and 34 species, with most Pomacentridae, Chaetodontidae, and Labridae. These three families present $91.91 \%$ of the total fish recorded/collected. The most abundant species were Dascyllus trimaculatus (2270 ind/ha) from Pomacentridae, Halichoeres prosopeion (1550 ind/ha) from Labridae, and Pomacentrus coelestis (95 ind/ha) from Pomacentridae. Shannon-Wiener diversity index value is 2.414 , and there were no dominant species observed.

\section{Acknowledgement}

This research was fully supported by PT Mitra Hijau Indonesia under developmental study project for Celukan Bawang Port area by PT Pelabuhan Indonesia Persero (Pelindo) III. The reviewer and ISFFS also corrected it.

\section{References}

1. N.K.A. Astiti, Forum Arkeolog. 31, 75-92 (2018)

2. Decree of Ministry of Transportation Indonesia No. KM 432 about National Port Master Plan (2017)

3. Regulation of Ministry of Transportation Indonesia No. PM 57 about Second Amendment to The Regulation of The Minister of Transportation Number PM 512015 about Seaport Operation (2020)

4. C. Rani, S. Yusuf, Torani J. Marine Science 4, 241-247 (2006)

5. S.S.A. Bakar, Master Thesis Makassar (ID) : Universitas Hasanudin (2018)

6. I. N. Edrus, M. Abrar, Indonesian Fish. Res. J. 22 (2016)

7. R.H. Kuiter, T. Tonozuka, Indonesian reef fish (Zoonetic, Australia, 2001)

8. G. Allen, Marine fishes of Southeast Asia (Periplus Editions, Singapore, 1999)

9. Government Regulation Number 22 of 2021 Appendix VII concerning Sea Water Quality Standards for Aquatic Biota

10. E.P. Odum, Fundamentals of ecology (in Bahasa Indonesia) (Gadjah Mada University Press, Yogyakarta, 1993)

11. Ministry of Environment of Republic of Indonesia Number 4 of 2001 about Standard Criteria for Coral Reef Damage

12. Giyanto, M. Abrar, T.A. Hadi, A. Budiyanto, M. Hafizt, A. Salataholy, M. Y. Iswari, Indonesia's coral reef status (BRIN, Jakarta, 2017)

13. K. Suwartimah, S. Redjeki, R.N. Pangripto W., Bul. Osean. Mar., 1, 73-81 (2016)

14. S. Nelson, Fishes of the world: 4th Ed., (John Wiley and Sons, New Jersey, 2006)

15. J.E. Randall, G.R. Allen, R.C. Steene, Fishes of The Great Barrier Reef and coral sea: 2nd edition (University of Hawaii Press, Hawaii, 1990)

16. H.W. Fricke, HelgoiEnder wiss. Meeresunters 30, 412-426 (1977)

17. W.T. White, P.R. Last, Dharmadi, R. Faizah, U. Chodrijah, B.I. Prisantoso, J.J. Pogonoski, M. Puckride, S.J.M. Blaber, Market fishes of Indonesia (Australian Centre for International Agricultural Research, Canberra, 2013)

18. I.N. Edrus, S.W. Wijaya, I.E. Setyawan, J. Pen. Perikan. Indo. 19, 175-186 (2013) 
19. R. Sala, D. Marsaoly, H.Y. Dasmasela, D. parenden, D. orisu, R. B. Tarigan, IOP Conf. Seri.Earth and Environ. Sci. 429 (2019)

20. M. Adrim, S.A. Harahap, K. Wibowo, Ilmu Kelaut. 17, 154-163 (2012)

21. A. Syakur, N.N. Wardana, J. Lit. Perikan. Ind. 12, 139-148 (2006)

22. C. Syms, G.P. Jones, Ecol. 81, 2714-2729 (2002) 